\title{
ŠKOTSKO-SLOVENSKO SODELOVANJE NA PODROČJU PODEŽELJA
}

Z geografskim oddelkom Univerze v Aberdeenu je Oddelek za geografijo Filozofske fakultete povezan že skoraj desetletje v okviru programa Socrates Erasmus. Naše sodelovanje se je na pobudo dr. Antona Gosarja začelo leta 1998 s t.i. intenzivnim programom (Intensive Program), ki vključuje več partnerskih univerz (Aberdeen, Lizbona, Sevilla, Palma de Mallorca, Innsbruck, Ljubljana, Vilnius). Oddelek za geografijo je bil dvakrat v vlogi organizatorja $(1998,2004)$, ko je kot študijo primera 30 profesorjem in študentom predstavil Koprsko Primorje z zaledjem (tematika: Gospodarjenje z obalnim območjem) in Zahodno Slovenijo (tematika: Razvoj podeželskih hribovitih območij).

Dosedanje sodelovanje smo želeli nadgraditi, zato je od 18. do 25. marca 2006 prišlo v Slovenijo 21 študentov podiplomskega študija (smeri sonaravni razvoj podeželja in gospodarjenje z zemljišči) in 2 profesorja. Študentje različnih profilov (geografi, pravniki, računovodje, agronomi itd.) so se za ta programa odločili, ker ima imenovana univerza zelo velik ugled in umešča kakovostne diplomante na ustrezne službe, ker je njihovo znanje na Otoku precej iskano.Zlasti so postali mednarodno odmevni pri pripravi metodologije za razvoj zavarovanih območij - naprej za Škotsko in potem za celotno državo. Slovenijo so si izbrali kot študijski primer spoznavanja razvoja podeželja v Evropski Zvezi. Osredotočili smo se na štiri vidike: delovanje skupnosti, trg nepremičnin, sonaravni razvoj kmetijstva ter mala podjetja in lokalno industrijo.

V prvih dneh smo poleg uvodnih predstavitev značilnosti slovenskega podeželja spoznavali in $\mathrm{z}$ večdnevnim terenskim delom ter večernimi analizami vrednotili razvojne možnosti Krasa, Vipavske doline in Vipavskih ter Goriških brd ter si ogledali Triglavski narodni park, Šavrine in Koprsko Primorje. V osmih dneh intenzivnega dela se je tako v naši družbi zvrstilo 32 informatorjev: predstavnikov univerz, raziskovalnih institucij, lokalne samouprave, društev, podjetnikov, kmetovalcev, domačinov in tujcev, ki so se v zadnjih letih priselili na Kras. Študentje so se sicer že na Škotskem predhodno pripravili z zbiranjem in kritičnim pretresom razpoložljive strokovne literature. Razdelili so se v štiri skupine, ki so preučevano območje analizirale vsaka s svojega vidika, zbirali dodatne informacije, se srečevali s ključnimi akterji, s pomočjo slovenskih študentov (šest slušateljev predmeta Geografija podeželja v 4. letniku) pa pridobivali potrebne informacije in iskali odgovore na zastavljena vprašanja. Njihova razmišljanja, ugotovitve in predloge za prihodnji razvoj so predstavili vsem udeležencem, povabili so tudi domačine iz Pliskovice (s katerimi so imeli tudi debatni večer) in poskrbeli za precej zanimivo, aktivno in celo polemično razpravo.

Tovrstno delo naj bi se nadaljevalo tudi v prihodnje, ker želimo zasnovati mrežo sodelavcev s področja razvoja podeželja, pa tudi pripraviti skupne raziskovalne projekte in terensko delo. 